\title{
Kandungan Hexenuronic Acid pada Pulp serta Pengaruhnya terhadap Kualitas Pulp dan Air Limbah: Tinjauan
}

\author{
Andri Taufick Rizaluddin', Krisna Septiningrum² \\ ${ }^{1}$ Balai Besar Pulp dan Kertas, Jl. Raya Dayeuhkolot 132, Bandung, Indonesia \\ ${ }^{2}$ Balai Besar Industri Agro, Jl. IR. Haji Juanda No.11, Paledang, Bogor, Indonesia
}

Diterima : 13 Juli 2018, Revisi akhir : 11 Desember 2018, Disetujui terbit : 17 Desember 2018

\section{Hexenuronic Acid Content on Pulp and its Effects on Pulp Quality and Wastewater: a Review}

\begin{abstract}
The wood active alkali cooking process will produce hexenuronic acid (HexA) originating from 4-O-methylglucuronoxylan of the glucuronoxylan group in hemicellulose. Hydrolysis process of HexA produces two types of furan compounds, namely 2-furancarboxylic acid (FA) and 5-formyl-2furancarboxylic acid (FFA). The HexA hydrolysis process contained in pulp and paper resulting from the cooking process is one of the causes of the yellowing process on paper due to exposure to moisture and heat from the environment. In addition, the HexA content of pulp can also increase the consumption of chemicals in the pulp and paper production process, especially in the bleaching process and testing of Kappa number parameters, and can also contribute to the content of organic chlorine soluble compounds in the waste water of the pulp and paper industry. There are several methods for reducing the HexA content of pulp and paper including by applying the oxidative chemical process to the bleaching process or by using an enzymatic process. Low HexA content, will be able to maintain pulp and paper from the occurrence of the pulp yellowing process, save on chemical consumption and reduce the adsorbable organic halides (AOX) content in wastewater.
\end{abstract}

Keywords: hexenuronic acid, wood cooking, Kappa number, AOX, enzymatic

\begin{abstract}
Abstrak
Proses pemasakan kayu dengan cara alkali aktif akan menghasilkan hexenuronic acid (HexA) yang berasal dari grup glucuronoxylan, tepatnya 4-O-methylglucuronoxylan pada hemiselulosa. Proses hidrolisis HexA menghasilkan dua jenis senyawa furan, yaitu 2-furancarboxylic acid (FA) dan 5-formyl2-furancarboxylic acid (FFA). Proses hidrolisis HexA hasil proses pemasakan dan terkandung dalam pulp dan kertas merupakan salah satu penyebab proses penguningan pada kertas akibat adanya paparan kelembapan dan panas dari lingkungan. Selain itu, kandungan HexA pada pulp juga dapat meningkatkan konsumsi bahan kimia pada proses produksi pulp dan kertas, terutama pada proses pemutihan dan pengujian parameter bilangan Kappa, serta dapat berkontribusi pada kandungan senyawa organik klorin terlarut dalam air limbah industri pulp dan kertas. Metode untuk menurunkan kandungan HexA dari pulp dan kertas antara lain dengan mengaplikasikan proses oksidatif kimia pada proses pemutihan atau dengan menggunakan proses enzimatis. Kandungan HexA yang rendah akan dapat mempertahankan pulp dan kertas dari terjadinya proses penguningan, menghemat konsumsi bahan kimia serta menurunkan kandungan adsorbable organic halides (AOX) pada air limbah.
\end{abstract}

Kata kunci: hexenuronic acid, pemasakan kayu, bilangan Kappa, AOX, enzimatis 


\section{Pendahuluan}

Industri pulp dan kertas merupakan salah satu industri yang memiliki pengaruh cukup signifikan terhadap lingkungan. Industri pulp dan kertas selain menggunakan sumber daya alam dengan kuantitas yang besar, juga mengkonsumsi energi, menggunakan air dan menghasilkan air limbah dengan kapasitas yang besar (Institute for Industrial Productivity, 2018; WWF, 2018). Oleh sebab itu, industri pulp dan kertas harus mengelola dan memonitor setiap pengaruh proses di industrinya terhadap lingkungan.

Proses alkali kraft adalah jenis proses pembuatan pulp yang umum digunakan industri pulp di Indonesia dengan bahan baku terutama jenis kayu daun lebar (hardwood). Kayu berdasarkan komponen kimianya disusun oleh komponen utama berupa selulosa, hemiselulosa, lignin dan komponen lain yang bersifat minor seperti zat ekstraktif dan mineral. Proses pemasakan alkali kraft pada industri pulp bertujuan untuk memisahkan lignin, ekstraktif, hemiselulosa serta bahan pengotor lain yang dipisahkan menjadi cairan black liquor untuk menghasilkan pulp yang memiliki kandungan kimia utama selulosa. Proses pemasakan bahan baku kayu tersebut biasanya akan menghasilkan reaksi-reaksi kimia yang terjadi pada komponen kimia kayu. Salah satu proses yang terjadi adalah proses terbentuknya hexenuronic acid (HexA) pada proses pemasakan kayu. HexA merupakan produk samping dari proses pemasakan kayu yang berasal dari hemiselulosa yang terdapat pada seluruh lapisan dinding sel kayu (Tabel 1).

Selain selulosa dan lignin, hemiselulosa merupakan salah satu kandungan utama dari kayu dan non kayu (non-wood). Hemiselulosa pada dasarnya dapat dibagi dua golongan, yaitu glucomannan dan glucuronoxylans. Jenis kayu daun lebar memiliki lebih banyak kandungan glucuronoxylan, sedangkan jenis kayu jarum memiliki lebih banyak kandungan glucomannan (Brogdon, 2009).

Tinjauan ini membahas proses terjadinya HexA, pengaruh kandungan HexA pada kualitas pulp seperti bilangan Kappa (Li and Gellerstedt, 1997; Chai et al., 2001), derajat cerah, proses penguningan pulp dan kertas (Teleman et al., 1996; Gellerstedt, 2007; Li et al., 2007; Liitiä and Tamminen, 2007; Kawae and Uchida, 2010b), proses pemutihan (Vourinen et al., 2007; Magara, Ikeda and Hosoya, 2009; Tarvo et al., 2010; Tavast et al., 2011; Andrade, Colodette and Oliveira, 2013). Tulisan ini juga membahas mengenai proses untuk menurunkan kandungan HexA pada pulp dan pengaruhnya terhadap kualitas air limbah. Tinjauan ini disampaikan untuk menggambarkan seberapa jauh pengaruh kandungan HexA pada pulp, mengingat belum ada industri pulp di Indonesia yang memperhitungkan kandungan HexA dalam proses pemasakan, pemutihan hingga pengolahan air limbahnya.

\section{Proses terjadinya Hexenuronic Acid pada Proses Pemasakan Alkali Kraft}

Proses pemasakan kayu secara alkali kraft untuk menghasilkan pulp yang merupakan bahan dasar kertas, menggunakan bahan kimia yang diukur berdasarkan nilai aktif alkali (AA) dan sulfiditas. Nilai ini ditentukan dengan perbandingan antara natrium hidroksida $(\mathrm{NaOH})$ dan natrium sulfida $\left(\mathrm{Na}_{2} \mathrm{~S}\right)$ untuk menghasilkan target bilangan Kappa yang diinginkan. Proses tersebut dilakukan dengan tujuan untuk memisahkan selulosa dari kandungan kayu lainnya untuk menghasilkan pulp yang merupakan bahan baku kertas.

Proses pemasakan kayu alkali kraft biasanya akan menghasilkan HexA yang berasal dari hemiselulosa glucuronoxylan.

Tabel 1. Distribusi Komponen Kimia pada Dinding Sel Kayu

\begin{tabular}{lccc}
\hline Lapisan Serat & Selulosa & Hemiselulosa & Lignin \\
\hline Lamela Tengah & 0 & 10 & 90 \\
Dinding Primer & 10 & 20 & 70 \\
Dinding Sekunder 1 & 35 & 25 & 40 \\
Dinding Sekunder 2 & 55 & 30 & 15 \\
Dinding Sekunder 3 & 55 & 40 & 5 \\
\hline Sumber: Haroen, (2016) & & &
\end{tabular}


Tabel 2. Komposisi Kandungan Glucuronoxylan pada Kayu (\%)

\begin{tabular}{lcc}
\hline Jenis Kayu & $\begin{array}{c}\text { Kandungan } \\
\text { Glucuronoxylan }\end{array}$ & $\begin{array}{c}\text { Kandungan } \\
\text { 4-O-methylglucuronic acid }\end{array}$ \\
\hline Kayu daun lebar Amerika Utara & $19,5-35,0$ & $2,6-5,5$ \\
Kayu daun lebar Skandinavia & 37,4 & 6,3 \\
Kayu daun lebar Eucalyptus & $14,4-26,0$ & $2,0-3,8$ \\
Kayu daun jarum Skandinavia & $14,1-14,8$ & $5,3-5,6$ \\
Kayu daun jarum Amerika Utara & $7,6-17,7$ & $1,8-6,0$ \\
\hline
\end{tabular}



Gambar 1. Proses Terjadinya HexA dari 4-O-methylglucuronoxylan (Teleman et al., 1996)

Secara spesifik, bagian HexA terbentuk dari grup 4-O-methyl- $\alpha$-D-glucopyranosyluronic acid (4-O-methylglucuronic acid) pada glucuronoxylan, yang setelah proses alkali akan berubah menjadigrup 4-deoxy-4-hexenuronic acid atau hexenuronic acid (Gambar 1) (Teleman et al., 1996). Komposisi kandungan glucuronoxylan bervariasi berdasarkan jenis kayu, yaitu berkisar 14,4-37,4\% pada kayu daun lebar dan 7,6-17,7\% pada kayu daun jarum, sedangkan kandungan
4-O-methylglucuronic acid pada kayu daun jarum berkisar 1,8-5,6\%, dan 2,0-6,3\% pada kayu daun lebar (Tabel 2). Perbedaan kandungan 4-O-methylglucuronic acid pada setiap jenis kayu tersebut akan menyebabkan proses pemasakan alkali kraft dengan bahan baku kayu berbeda akan menghasilkan pulp yang mengandung HexA dalam jumlah berbeda pula.

Nilai parameter AA, temperatur, dan waktu pemasakan ( $H$ factor) pada proses pemasakan kraft, akan secara signifikan mempengaruhi proses pembentukan HexA, sedangkan nilai sulfiditas (S) tidak memiliki pengaruh yang cukup signifikan. Proses terbentuknya HexA juga dipengaruhi oleh jenis kayu yang disebabkan oleh adanya variasi pada kandungan 4-O-methylglucuronoxylan dan perbedaan struktur kayu. Selain itu metode pemasakan pulp juga memiliki pengaruh terhadap HexA yang dihasilkan. Faktor-faktor pada pemasakan yang mempengaruhi pembentukan kandungan HexA disajikan selengkapnya pada Tabel 3. Selain terkandung pada pulp kraft, sebagian grup HexA akan terpisahkan dan teridentifikasi pada xylan yang terdapat pada black liquor yang dipisahkan dari pulp kraft (Magaton et al., 2011). Beberapa kandungan HexA setelah proses pemasakan kraft dari beberapa jenis bahan baku kayu dapat dilihat pada Tabel 4.

Tabel 3. Faktor-faktor pada Pemasakan yang Berpengaruh pada Pembentukan Kandungan HexA

\begin{tabular}{lc}
\hline Faktor-faktor & Literatur \\
\hline Faktor H & Chai et al., 2001; Pedroso and Carvalho, 2003 \\
Spesies kayu/struktur kayu/kandungan & Chai et al., 2001; Lindström et al., 2011; Magaton et \\
4-O-Methylglucuronoxylan & al., 2011 \\
Efektif alkali (EA)/aktif alkali (AA) & Pedroso and Carvalho, 2003 \\
Metode pemasakan & Takahashi, Nakagawa-izumi and Ohi, 2011 \\
\hline
\end{tabular}


Tabel 4. Pengaruh HexA terhadap Bilangan Kappa

\begin{tabular}{|c|c|c|c|c|c|c|c|}
\hline No & Bahan baku & Proses & $\begin{array}{c}\text { Faktor } \\
\mathrm{H}\end{array}$ & $\begin{array}{c}\text { Kappa } \\
\text { number } \\
(\mathrm{KN})\end{array}$ & $\begin{array}{c}\text { HexA } \\
\text { Content } \\
(\mathrm{mmol} / \\
\mathrm{kg})\end{array}$ & $\begin{array}{l}\text { KN dari } \\
\text { HexA }\end{array}$ & Literatur \\
\hline & \multicolumn{7}{|c|}{ Jenis Kayu Daun Lebar } \\
\hline 1 & Birch & Kraft & - & $11,1-19,2$ & $38,0-69,0$ & $24-36 \%$ & $\begin{array}{c}\text { Li and Gellerstedt, } \\
1997\end{array}$ \\
\hline 2 & Maple & Kraft & 2281 & 13,0 & - & $40 \%$ & Chai et al., 2001 \\
\hline 3 & Eucalyptus & Kraft & - & 16,65 & 78,06 & $40.3 \% *$ & $\begin{array}{l}\text { Bacarin et al., } \\
2017\end{array}$ \\
\hline 4 & Eucalyptus & Kraft & - & 17,2 & - & $43 \%$ & Gellerstedt, 2007 \\
\hline 5 & Birch & Kraft & - & 13,6 & - & $33 \%$ & Gellerstedt, 2007 \\
\hline \multirow[t]{2}{*}{6} & \multirow[t]{2}{*}{ Birch } & \multirow[t]{2}{*}{ Kraft } & - & 16,4 & $44,4-48,0$ & $\begin{array}{c}23,3- \\
25,2 \% *\end{array}$ & \multirow[t]{2}{*}{ Li et al., 2007} \\
\hline & & & - & 16,0 & $48,7-55,0$ & $\begin{array}{c}26,2- \\
29,6 \% *\end{array}$ & \\
\hline 7 & Hardwood & Kraft & - & 14,5 & 34,9 & $20,7 \% *$ & $\begin{array}{l}\text { Nguyen et al., } \\
2008\end{array}$ \\
\hline \multirow[t]{2}{*}{8} & \multirow{2}{*}{$\begin{array}{l}\text { Eucalyptus } \\
\text { Camaldulensis }\end{array}$} & Kraft (SuperBatch) & 1018 & 13,4 & 37,1 & $24 \%$ & \multirow{2}{*}{$\begin{array}{l}\text { Fatehi, Malinen } \\
\text { and Ni, } 2009\end{array}$} \\
\hline & & $\begin{array}{l}\text { Kraft (Isoterm } \\
\text { Cooking) }\end{array}$ & 1018 & 15,4 & 63,2 & $35 \%$ & \\
\hline \multirow[t]{4}{*}{9} & \multirow[t]{4}{*}{ Acacia mearnsii } & Kraft & 291 & $19.5-28,9$ & $34,9-35,6$ & $\begin{array}{c}10,6- \\
15,4 \% *\end{array}$ & \multirow{4}{*}{$\begin{array}{c}\text { Takahashi, } \\
\text { Nakagawa-izumi } \\
\text { and Ohi, } 2011\end{array}$} \\
\hline & & Kraft-AQ & & $20,9-23,7$ & $32,4-35,7$ & $\begin{array}{c}11,8- \\
14,7 \% *\end{array}$ & \\
\hline & & PS & & $19,7-26,3$ & $32,0-36,3$ & $\begin{array}{c}11,2- \\
15,8 \% *\end{array}$ & \\
\hline & & PS-AQ & & 21,4 & 32,8 & $13,2 \% *$ & \\
\hline \multirow[t]{3}{*}{10} & \multirow{3}{*}{$\begin{array}{l}\text { Eucalyptus } \\
\text { globulus }\end{array}$} & Kraft (SuperBatch) & 300 & 16,5 & \pm 51 & $29 \%$ & \multirow{6}{*}{$\begin{array}{c}\text { Antes and } \\
\text { Joutsimo, } 2015\end{array}$} \\
\hline & & $\begin{array}{c}\text { Kraft } \\
\text { (CompactCooking) }\end{array}$ & 239 & 17,0 & \pm 61 & $30 \%$ & \\
\hline & & Kraft (Lo-Solids) & 244 & 17,0 & \pm 51 & $28 \%$ & \\
\hline \multirow[t]{3}{*}{11} & \multirow{3}{*}{$\begin{array}{l}\text { Eucalyptus } \\
\text { nitens }\end{array}$} & Kraft (SuperBatch) & 315 & 17,0 & \pm 52 & $26 \%$ & \\
\hline & & $\begin{array}{c}\text { Kraft } \\
\text { (CompactCooking) }\end{array}$ & 262 & 16,5 & \pm 54 & $28 \%$ & \\
\hline & & Kraft (Lo-Solids) & 273 & 16,5 & \pm 51 & $26 \%$ & \\
\hline \multirow[t]{2}{*}{12} & \multirow[t]{2}{*}{ Acacia mearnsii } & Kraft & 496 & 24,5 & 55,0 & $19,3 \% *$ & \multirow{2}{*}{$\begin{array}{l}\text { Rizaluddin et al., } \\
2015\end{array}$} \\
\hline & & Prehidrolisis-kraft & 496 & 13,2 & 18,0 & $11,7 \% *$ & \\
\hline 13 & $\begin{array}{l}\text { Eucalyptus } \\
\text { hybrid }\end{array}$ & Prehidrolisis-kraft & 496 & 13,0 & 41,2 & $27,3 \% *$ & $\begin{array}{l}\text { Rizaluddin et al., } \\
2016\end{array}$ \\
\hline 14 & $\begin{array}{l}\text { Eucalyptus } \\
\text { globulus }\end{array}$ & & 496 & 32,3 & 13,2 & $3,5 \% *$ & \\
\hline \multirow[t]{3}{*}{15} & \multirow[t]{3}{*}{ Eucalyptus } & \multirow[t]{3}{*}{ Kraft } & 441 & 16,6 & 55,9 & $29,0 \% *$ & \multirow{3}{*}{$\begin{array}{l}\text { Ventorim, Favaro } \\
\text { and Frigieri, } 2016\end{array}$} \\
\hline & & & 677 & 16,8 & 45,8 & $23,4 \% *$ & \\
\hline & & & 1031 & 16,9 & 52,6 & $26,8 \% *$ & \\
\hline
\end{tabular}




\begin{tabular}{|c|c|c|c|c|c|c|c|}
\hline \multirow{3}{*}{1} & Jenis Kayu Dau & arum & & & & & \\
\hline & \multirow[t]{2}{*}{ Pine } & Kraft & - & 18,6 & - & $10,2 \%$ & Gellerstedt, 2007 \\
\hline & & Soda/Anthraquinone & - & 18,9 & - & $1,6 \%$ & Gellerstedt, 2007 \\
\hline 2 & Softwood & Kraft & - & 31,8 & 21,8 & $5,9 \% *$ & $\begin{array}{l}\text { Nguyen et al., } \\
2008\end{array}$ \\
\hline \multirow[t]{2}{*}{3} & \multirow[t]{2}{*}{ Japanese larch } & Kraft & 1239 & 23,6 & 5,2 & $1,9 \% *$ & Takahashi, \\
\hline & & $\begin{array}{l}\text { Polisulfida- } \\
\text { Anthraquinone }\end{array}$ & 1549 & 23,6 & 13,7 & $5 \% *$ & $\begin{array}{l}\text { Nakagawa-izumi } \\
\text { and Ohi, } 2011\end{array}$ \\
\hline
\end{tabular}

Keterangan: * = berdasarkan perhitungan 0,86 bilangan Kappa $10 \mu \mathrm{mol} \mathrm{HexA} \mathrm{(Li} \mathrm{and} \mathrm{Gellerstedt,} \mathrm{1997;} \mathrm{Chai} \mathrm{et} \mathrm{al.,} \mathrm{2001)}$

\section{Reaksi HexA pada Analisis Bilangan Kappa}

Kandungan HexA pada pulp dapat memberikan pengaruh pada perhitungan nilai bilangan Kappa pulp. Hal ini disebabkan ikatan HexA yang memiliki struktur ikatan ganda dapat bereaksi dengan beberapa pereaksi elektrofilik. Struktur ini mengandung ikatan karbon-karbon seperti pada lignin yang dapat mengkonsumsi bahan kimia $\mathrm{KMnO}_{4}$ pada analisis bilangan Kappa. Kandungan HexA akan menyebabkan kesalahan pada perhitungan bilangan Kappa, dan akan menghasilkan ketidaksesuaian informasi data kandungan lignin pada pulp belum putih. Kontribusi HexA pada bilangan Kappa lebih besar pada kayu daun lebar dibandingkan dengan kayu daun jarum. Pada kayu daun jarum, kontribusi kandungan HexA pada bilangan Kappa sekitar 10\% (dan lebih rendah), sedangkan pada kayu daun lebar kandungan HexA memberikan kontribusi pada bilangan Kappa berkisar $15-50 \%$. Hal ini karena kayu daun lebar memiliki kandungan glucuronoxylan yang lebih tinggi (Li and Gellerstedt, 1997; Chai et al., 2001; Brogdon, 2009). Secara spesifik, Li dan Gellerstedt menemukan bahwa kandungan HexA pada pulp akan mengkonsumsi sekitar 8,6 equivalen $\mathrm{KMnO}_{4}$ per mol HexA berdasarkan konsumsi berbagai model HexA dan senyawa antaranya (Li and Gellerstedt, 1997). Penelitian yang sama juga menyebutkan bahwa HexA akan memberikan kontribusi sebesar 0,86 bilangan Kappa per $10 \mu \mathrm{mol} \mathrm{HexA,} \mathrm{atau} \mathrm{tiap} \mathrm{11,6} \mathrm{-} \mathrm{13,7} \mu \mathrm{g}$ HexA setara dengan satu unit bilangan Kappa ( $\mathrm{Li}$ and Gellerstedt, 1997; Chai et al., 2001). Chai menambahkan bahwa kontribusi HexA pada perhitungan bilangan Kappa tersebut kurang dari $10 \%$ bila bilangan Kappa di atas 30, namun pengaruh HexA terhadap perhitungan bilangan Kappa akan menjadi signifikan pada bilangan Kappa yang rendah, dan pengaruhnya dapat

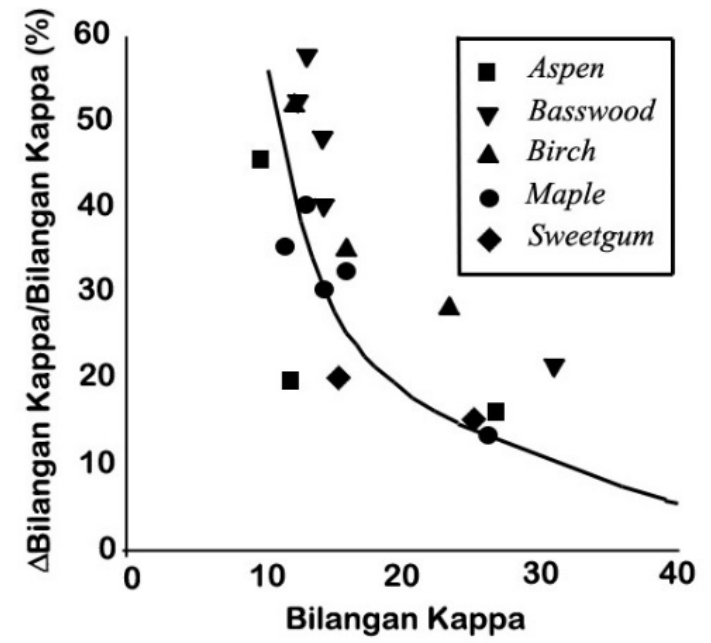

Gambar 2. Kontribusi Reduksi Bilangan Kappa akibat HexA ( $\triangle$ Bilangan Kappa) Relatif terhadap Bilangan Kappa Total (Chai et al., 2001)

mencapai 50\% pada bilangan Kappa di bawah 10 (Gambar 2) (Chai et al., 2001). Beberapa pengaruh HexA terhadap bilangan Kappa pada berbagai jenis kayu dan proses pemasakan pulp disajikan pada Tabel 4.

\section{Proses Penguningan Akibat Hexenuronic Acid}

Selain berpengaruh pada bilangan Kappa, kandungan HexA pada pulp juga dianggap memiliki hubungan yang kuat dengan terjadinya proses penguningan pada kertas. Kertas akan mengalami proses penguningan seiring dengan bertambahnya umur pakai kertas. Proses penguningan ini cenderung terjadi pada keadaan lingkungan lembap dan panas yang merupakan kondisi alami lingkungan di Indonesia. Proses penguningan pulp yang disebabkan oleh kandungan HexA pada pulp masih belum diketahui prosesnya secara lengkap. Beberapa penelitian telah menemukan hubungan yang 
kuat antara kandungan HexA dan terjadinya proses penguningan pada kertas, baik pada kertas yang diputihkan dengan proses pemutihan ECF maupun dengan proses pemutihan total chlorine free (TCF).

Beberapa penelitian membuktikan hubungan antara kandungan HexA pada pulp, kandungan moisture, viskositas dan kandungan logam transisi $\mathrm{Fe}$ dan $\mathrm{Cu}$ dengan proses penguningan pada kondisi panas menggunakan pulp kraft kayu daun lebar yang diputihkan dengan proses ECF maupun TCF. Pulp dengan kandungan HexA yang lebih tinggi akan cenderung sangat sensitif terhadap proses penguningan yang disebabkan pengaruh panas, bahkan pada keadaan kering sekalipun. Penelitian yang sama juga menemukan bahwa proses terjadinya penguningan pulp ECF adalah sama atau sedikit lebih tinggi dibandingkan dengan pulp TCF pada kisaran kandungan HexA yang sama (Kawae and Uchida, 2010a; Silva et al., 2011) yang disebabkan oleh rendahnya reaktivitas klorin dioksida terhadap HexA. Hasil berbeda ditunjukkan oleh penelitian Cadena (Cadena, Vidal and Torres, 2010) bahwa pulp yang melalui proses pemutihan TCF memiliki kecenderungan proses kehilangan derajat cerah lebih besar daripada pulp yang melalui proses ECF.

Proses penguningan akibat HexA terjadi setidaknya dengan dua reaksi, pertama terjadi tahap awal yang dipengaruhi oleh suhu (panas), dan pada tahap akhir yang dipengaruhi oleh kelembapan atau adanya kadar air. Proses hidrolisis HexA akan membentuk dua jenis senyawa furan, yaitu 2-furancarboxylic acid (FA) dan 5-formyl-2-furancarboxylic acid (FFA) (Gambar 3), serta terlepas ion mangan dan ion besi yang terikat oleh HexA. FFA dan FA merupakan produk turunan hidrolisis utama dari HexA (Teleman et al., 1996; Gellerstedt, 2007) (Teleman et al., 1996; Gellerstedt, 2007; Li et al., 2007; Liitiä and Tamminen, 2007; Kawae and Uchida, 2010b). Liitia dan Tamminen membuktikan lebih lanjut bahwa HexA pada nilai absorbansi $240 \mathrm{~nm}$ akan perlahan terdegradasi dan terbentuk FFA pada nilai absorbansi $285 \mathrm{~nm}$ sebagai spektrum warna baru selama proses penguningan akibat panas dan kelembapan. FFA sebenarnya tidak berwarna, namun pada keadaan lembap akan bereaksi membentuk struktur warna dengan nilai absorbansi di atas $320 \mathrm{~nm}$ (Liitiä and Tamminen, 2007).

\section{Efek Kandungan HexApada Proses Pemutihan}

Proses pemutihan pulp dengan metode ECF klorin dioksida akan membentuk klorit, klorat, hipoklorit, klorida, dan klorin sebagai hasil reaksi sampingan. Selain itu juga akan terbentuk senyawa organik klorin baik soluble (merupakan salah satu jenis halogenated organic atau adsorbable organic halides (AOX) maupun insoluble (OX) (Gambar 4). Walaupun klorin dioksida memiliki reaksi yang lebih kuat dengan lignin dibandingkan dengan HexA, pada proses pemutihan klorin dioksida ini<smiles>O=C(O)C1=C[C@@H](O)[C@H](O)[C@H](O)O1</smiles><smiles>[CH-]</smiles><smiles>C1CCCC1</smiles><smiles>O=C[C@H](O)c1cccc(C(=O)O)c1</smiles><smiles>[CH]1[CH]C[CH]1</smiles>
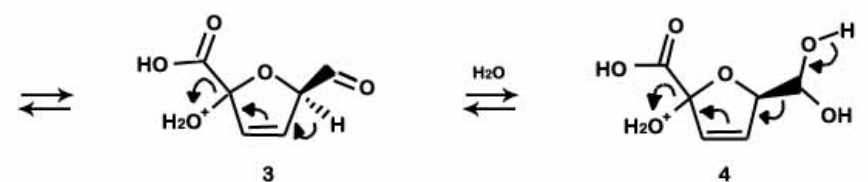

4
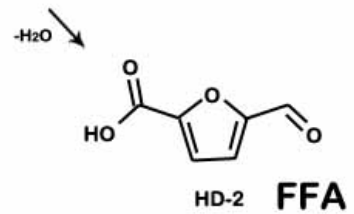<smiles>CC(C)OC(C)C(C)O</smiles>
$\stackrel{-\mathrm{HCO}_{2} \mathrm{H}}{-\mathrm{H}_{2} \mathrm{O}}$<smiles>O=C[C@H](O)C=CC(=O)C(=O)O</smiles>

FA

Gambar 3. Proses terjadinya Hidrolisis Asam pada HexA (Teleman et al., 1996)

$(\mathrm{FA}=$ 2-furancarboxylic acid, sedangkan $\mathrm{FFA}=5$-formyl-2-furancarboxylic acid $)$ 


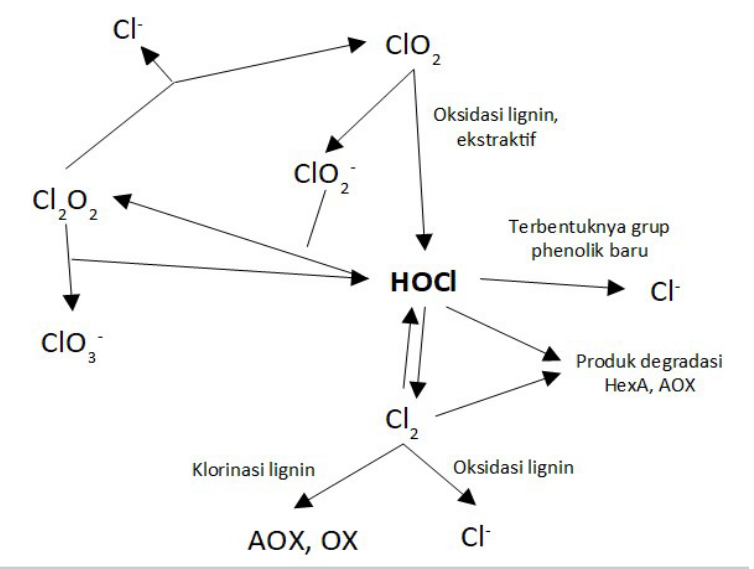

Gambar 4. Model Delignifikasi Klorin Dioksida dan Hubungannya dengan HexA dan AOX (Tarvo, 2010)

HexA akan terdegradasi (pada kondisi alkali), dan akan terdegradasi lebih lanjut pada proses ekstraksi alkali dan proses hidrogen peroksida yang mengikuti proses tersebut. Dekomposisi HexA disebabkan oleh asam hipoklorit $(\mathrm{HOCl})$ atau produk kesetimbangannya yaitu klorin $\left(\mathrm{Cl}_{2}\right)$ (Gambar 5). Asam hipoklorit bereaksi sangat cepat terhadap HexA dibandingkan dengan lignin (Vourinen et al., 2007; Magara, Ikeda and Hosoya, 2009). Pada proses pemutihan klorin dioksida (tanpa kehadiran asam hypochlorous), dua ekuivalen klorin dioksida akan bereaksi dengan struktur lignin fenolik, dimana satu ekuivalen asam klorit $\left(\mathrm{ClO}_{2}^{-}\right)$dan satu ekuivalen asam hipoklorit akan terbentuk (Vourinen et al., 2007). Model proses delignifikasi klorin dioksida dan hubungannya dengan HexA dan AOX dapat dilihat pada Gambar 4 (Tarvo et al., 2010).

Hal yang sama terjadi pada proses pemutihan ozon, HexA akan terdegradasi pada kondisi alkali, dan akan terdegradasi lebih lanjut pada proses ekstraksi alkali maupun hidrogen peroksida yang mengikuti proses ozon. Dibandingkan klorin dioksida dan asam sulfat, ozon memiliki reaksi pada HexA lebih kuat sebesar 2,4 kali, selain itu ozon memiliki reaksi pada HexA yang lebih kuat daripada dengan lignin (Ventorim et al., 2008). Pengaruh proses pemutihan terhadap kandungan HexA dapat dilihat selengkapnya pada Tabel 5.

Selain proses pemutihan, proses pra pengolahan seperti tahap asam (A-stage) pada tahap awal pemutihan dapat menurunkan kandungan HexA secara selektif. Pulp yang tidak melalui tahap perlakuan awal asam sebelum $\mathrm{D}_{0}$ akan memiliki nilai kandungan HexA hampir dua kali lipat dibandingkan dengan pulp yang melalui tahap asam sebelum $\mathrm{D}_{0}$ (Lehtimaa et al., 2010). Namun jumlah penurunan HexA pada proses D akan berkurang bila telah menggunakan tahap A sebelumnya. Hal ini dikarenakan lebih sedikitnya kandungan HexA pada pulp yang telah melalui tahap A sehingga akan memperlambat proses, dan sebagian dari asam hipoklorit dapat terkonsumsi oleh produk hasil reaksi tahap asam.

Pada penelitian lain ditemukan bahwa penggunaan tahap asam (A) pada tahapan ECF: $\mathrm{AD}(\mathrm{EP}) \mathrm{D}$ dapat menurunkan konsumsi total aktif klorin untuk mencapai tingkat kecerahan (brightness) yang sama, dan menghasilkan tingkat viskositas yang lebih tinggi dibandingkan proses pemutihan klorin dioksida panas $\left(\mathrm{D}_{\mathrm{HT}}\right)$ dengan tahap $\mathrm{D}_{\mathrm{HT}}(\mathrm{EP}) \mathrm{DP}$ (Andrade, Colodette and Oliveira, 2013). Sementara itu, penelitian Tavast dkk. mengusulkan tahap kombinasi peracetic acid $(\mathrm{T})$ pada tahapan klorin dioksida (D), dengan tahapan A(DT), dengan klorin dioksida ditambahkan sebelum peracetic acid (Tavast et al., 2011). Pulp yang didapat dari tahapan tersebut memiliki $\mathrm{KN}$ dan kandungan HexA yang lebih rendah dibandingkan dengan

HexA-O-XYLAN $+\mathrm{HOCl} \stackrel{\text { HoCl. } \mathrm{H}_{2} \mathrm{O}}{>}$ 2-oxo-hexaric acid $+2 \mathrm{HCl}+\mathrm{XYLAN-OH}$

$\mathrm{HexA}-\mathrm{O}-\mathrm{XYLAN}+\mathrm{Cl}_{2} \stackrel{\text { HOCl. }_{2} \mathrm{O}}{\longrightarrow}$ 3-deoxy-3-chloro-2-oxohexaric acid $+2 \mathrm{HCl}+\mathrm{XYLAN-OH}$

HexA--O-XYLAN $+\mathrm{HOCl} \stackrel{\text { HOCl. } \mathrm{H}_{2} \mathrm{O}}{\longrightarrow}$ 2-oxo-hexaric acid $+\mathrm{HCl}+\mathrm{Cl}^{-}+\mathrm{XYLAN}-\mathrm{OH}$

$\mathrm{HexA}^{-}-\mathrm{O}-\mathrm{XYLAN}+\mathrm{Cl}_{2} \stackrel{\mathrm{HOCl}_{2} \mathrm{O}}{\longrightarrow}$ 3-deoxy-3-chloro-2-oxohexaric acid $+2 \mathrm{HCl}+\mathrm{Cl}^{-}+\mathrm{XYLAN}^{-\mathrm{OH}}$

Gambar 5. Reaksi Kandungan HexA pada Pulp yang disebabkan oleh Senyawa Hipoklorit dan Klorin (Tarvo et al., 2010) 
Tabel 5. Pengaruh Kandungan HexA terhadap Proses Penguningan Pulp dan Kertas

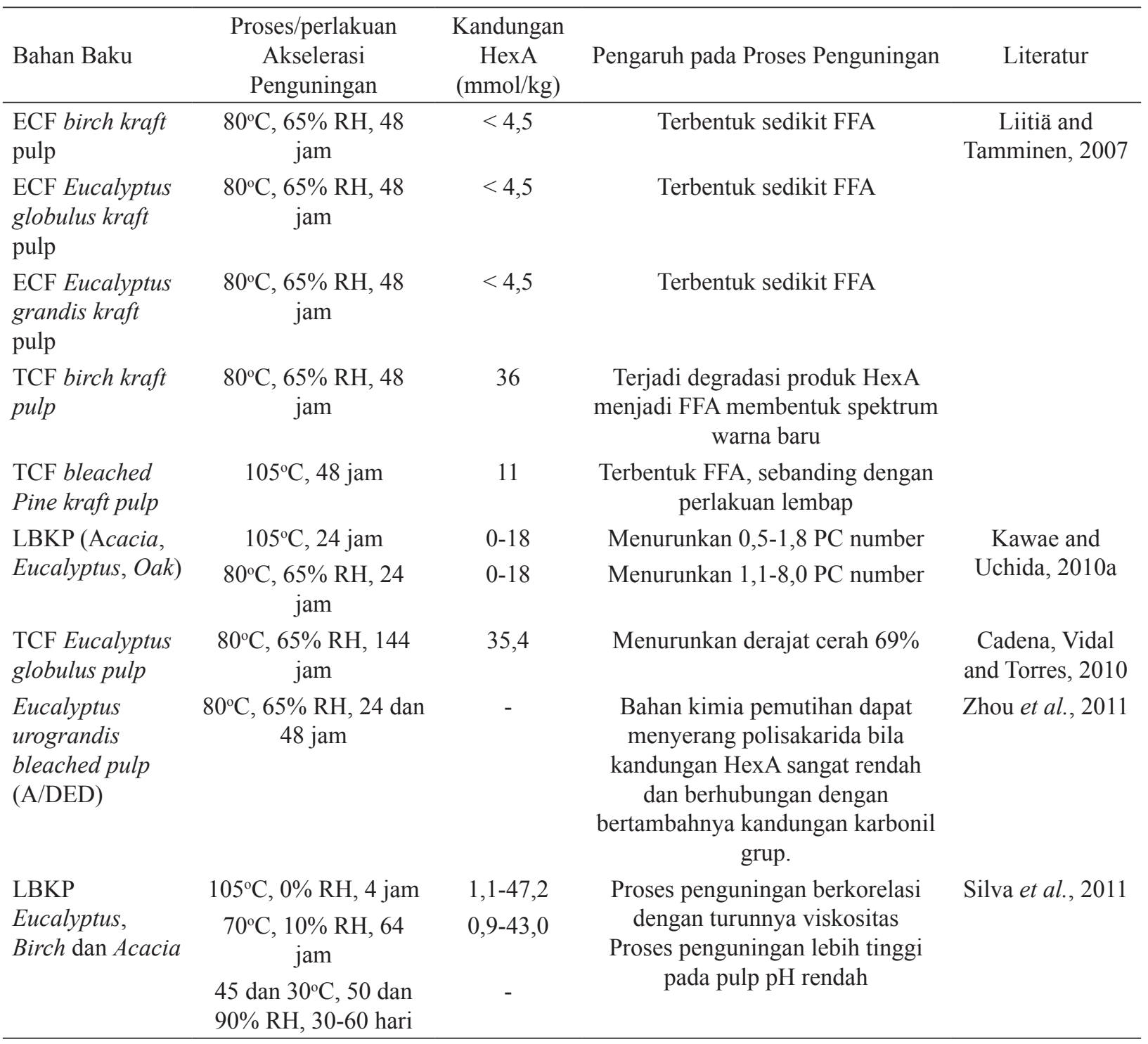

Keterangan: $P C$ number $=$ bilangan Post Color, $\mathrm{RH}=$ relative humidity (kelembapan udara relatif), LBKP $=$ leaf bleached kraft pulp $($ pulp kayu daun lebar yang telah diputihkan), A/DED = asam/ klor dioksida-ekstraksi-klor dioksida

Tabel 6. Pengaruh Perlakuan Proses Pemutihan terhadap Kandungan HexA

\begin{tabular}{|c|c|c|c|}
\hline Proses & Efek & $\begin{array}{c}\text { Proses } \\
\text { Pemutihan }\end{array}$ & Literatur \\
\hline $\begin{array}{l}\text { Proses pemutihan ECF } \\
\text { pada oxygen bleached } \\
\text { Eucalyptus kraft pulp }\end{array}$ & $\begin{array}{l}\text { Kandungan HexA dapat mengkonsumsi } \\
\text { klorin dioksida (dengan lambat) }\end{array}$ & DEDD & $\begin{array}{c}\text { Costa and Colodette, } \\
2007\end{array}$ \\
\hline \multirow[t]{3}{*}{$\begin{array}{l}\text { Aplikasi } \mathrm{ClO}_{2}, \mathrm{O}_{3} \text {, dan } \\
\mathrm{H}_{2} \mathrm{SO}_{4} \text { pada unbleached } \\
\text { dan oxygen-delignified } \\
\text { Eucalyptus kraft pulp }\end{array}$} & $\begin{array}{l}\text { Reaksi } \mathrm{ClO}_{2} \text { pada lignin dua kali lebih } \\
\text { cepat daripada HexA, namun tetap } \\
\text { signifikan } \\
\text { Reaksi } \mathrm{ClO}_{2} \text { pada HexA lebih tinggi bila } \\
\text { terdapat lignin }\end{array}$ & $\mathrm{D}_{0}$ & Ventorim et al., 2008 \\
\hline & $\begin{array}{l}\text { HexA bereaksi paling cepat dengan } \mathrm{O}_{3} \text {, } \\
\text { lalu dengan } \mathrm{ClO}_{2} \text { baru } \mathrm{H}_{2} \mathrm{SO}_{4}\end{array}$ & $\mathrm{~A}_{\mathrm{HT}}$ & \\
\hline & $\begin{array}{c}\text { Ozon bereaksi 2,4 kali lebih cepat dengan } \\
\text { HexA daripada dengan lignin }\end{array}$ & $\mathrm{Z}$ & \\
\hline
\end{tabular}




\author{
Aplikasi klor dioksida \\ (D) dibandingkan \\ dengan ozon $(Z)$ pada \\ LOKP
}

Aplikasi proses alkali

(A) pada O-bleached

birch kraft pulp

Aplikasi proses asam

perasetat $(\mathrm{T})$ pada

E.globulus kraft pulp

Proses pemutihan klorin

dioksida pada pulp

Eucalyptus urograndis

dengan kandungan

HexA rendah

Aplikasi proses alkali pada Eucalyptus dan

Pine kraft pulp

Proses pemutihan

ozon yang diikuti

oleh ekstraksi dengan

penambahan hidrogen

peroksida

Proses pemutihan asam peroksimonosulfat yang diikuti oleh proses ozon, serta ekstraksi dengan penambahan hidrogen peroksida

Proses reaksi peroksimonosulfat pada

filtrat dari pulp yang

telah diputihkan

Oksigen delignifikasi pada Eucalyptus kraft pulp
$\mathrm{D}_{0} \mathrm{OPD}_{1}$ memiliki kandungan HexA

tertinggi pada nilai derajat cerah yang sama

Aplikasi proses A dapat menurunkan kandungan HexA 45\% dengan $A$ stage sehingga dapat lebih efektif menurunkan $\operatorname{lignin}(\mathrm{KN})$

$$
\begin{gathered}
\text { Aplikasi proses T dapat menghasilkan } \\
\text { selektivitas yang lebih tinggi dan } \\
\text { menurunkan HexA }
\end{gathered}
$$

Bahan kimia pemutihan dapat menyerang polisakarida bila kandungan HexA sangat rendah dan berhubungan dengan bertambahnya kandungan grup karbonil.
Aplikasi proses alkali sebelum proses pemutihan dapat menurunkan KN dan sedikit HexA Aplikasi proses $\mathrm{Z}$ dan $\mathrm{P}_{\text {sa }}$ dapat sama-
sama menurunkan kandungan HexA

$\begin{array}{cc}\text { CEHD } & \text { Kawae and Uchida, } \\ \mathrm{D}_{0} \mathrm{EPD}_{1} & 2010 \mathrm{~b}\end{array}$

AZEPD

$\mathrm{D}_{0}$ vs $\mathrm{AD}_{0} \quad$ Lehtimaa et al., 2010

DT

Tavast et al., 2011

ADED

Zhou et al., 2011

$\begin{array}{cc}\mathrm{ADE}_{\mathrm{p}} \mathrm{D} & \text { Andrade, Colodette and } \\ \mathrm{A} / \mathrm{DE}_{\mathrm{p}} \mathrm{DP} & \text { Oliveira, 2013 } \\ \mathrm{D}_{\mathrm{HT}} \mathrm{E}_{\mathrm{p}} \mathrm{DP} & \end{array}$

$\mathrm{OZE}_{\mathrm{p}} \quad$ Rizaluddin et al., 2015

Keterangan proses pemutihan: $\mathrm{A}=$ asam $\left(\mathrm{H}_{2} \mathrm{SO}_{4}\right), \mathrm{C}=$ klorin, $\mathrm{D}=\mathrm{D}_{0}=$ klor dioksida, $\mathrm{O}=$ oksigen, $\mathrm{Z}=$ ozon, $\mathrm{P}=$ hidrogen peroksida, $\mathrm{P}_{\mathrm{sa}}=$ asam peroksimonosulfat, $\mathrm{T}=$ asam perasetat, $\mathrm{E}=$ ekstraksi, $\mathrm{E}_{\mathrm{p}}=$ ekstraksi + hidrogen peroksida, $\mathrm{Q}=$ tahap chelating, $\mathrm{H}=$ asam hipoklorit, $\mathrm{HT}$ $=$ temperatur tinggi, $\mathrm{X}=$ perlakuan enzim

tahapan konvensional $\left(\mathrm{D}, \mathrm{D}_{0}\right)$ dan tahapan peracetic acid $(\mathrm{T})$ secara terpisah. Sementara itu, penelitian lain (Yoshida and Koshitsuka, 2008; Yoon et al., 2012; Rizaluddin et al., 2015) mengusulkan bahwa tahap A dapat diganti dengan tahap asam peroksimonosulfat $\left(\mathrm{P}_{\mathrm{sa}}\right)$ yang selain bereaksi dengan HexA, menurunkan kandungan lignin (menurunkan $\mathrm{KN}$ ) dari pulp, juga dapat menurunkan konsumsi total aktif klorin.

\section{Pengaruh Kandungan HexA pada Air Limbah}

Kandungan HexA pada pulp akan menyebabkan pemborosan penggunaan bahan kimia pada 
proses pembuatan pulp dan kertas. Pemborosan bahan kimia terjadi pada proses analisis bilangan Kappa, yaitu kalium permanganat $\left(\mathrm{KMnO}_{4}\right)$, dan pada proses pemutihan pulp. Reaksi antara kalium permanganat dengan kandungan HexA pada pulp selain akan memberikan informasi data yang salah mengenai kandungan lignin pada pulp juga dapat menyebabkan pemakaian kalium permanganat yang berlebih $\left(8,6\right.$ equivalen $\mathrm{KMnO}_{4}$ per mol HexA) dan akan menghasilkan air limbah yang lebih banyak ( $\mathrm{Li}$ and Gellerstedt, 1997). Kandungan HexA juga dapat bereaksi dengan bahan kimia pemutihan pulp seperti oksigen, klorin dioksida, ozon ataupun asam peroksimonosulfat, yang sejatinya ditujukan pada lignin, sehingga menimbulkan pemborosan bahan kimia dan menghasilkan air limbah pencucian yang lebih banyak. Costa dan Colodette menyebutkan bahwa dari total dosis klorin dioksida yang dikonsumsi untuk memutihkan pulp dengan tahapan DEDD, sebanyak $42,4 \%$ konsumsi klorin dioksida tersebut ternyata beraksi dengan HexA, dan hanya 41,6\% yang bereaksi dengan lignin (Costa and Colodette, 2007). Ozon memiliki laju reaksi dengan HexA 2,4 kali lebih tinggi daripada dengan lignin (Ventorim et al., 2008), sehingga diperkirakan penambahan dosis ozon akan bereaksi dengan lignin maupun dengan HexA. Sementara itu Rizaluddin et al., (2015) menyebutkan bahwa penambahan dosis asam peroksimonosulfat juga memiliki kecenderungan untuk dapat menurunkan kandungan HexA dan lignin seperti penambahan ozon.

Kandungan HexA pada pulp juga akan berpengaruh pada kualitas air limbah yang dihasilkan dari proses pemutihan ECF. Kandungan HexA pada proses pemutihan pulp kraft Eucalyptus menggunakan proses ECF cenderung akan menghasilkan kandungan absorbable organic halides (AOX) yang lebih besar pada air limbahnya yang ditunjukkan dalam Tabel 7 .
Beberapa penelitian merumuskan suatu hubungan antaraAOX yang terbentuk dengan dosis klorin dioksida dan asam sulfat yang digunakan pada proses pemutihan serta pembentukan AOX pada air limbah. Hal tersebut terjadi karena HexA dapat mengkonsumsi $\mathrm{ClO}_{2}$ selama proses pemutihan dan meningkatkan kandungan AOX. Secara spesifik hal ini dikarenakan adanya asam hipoklorit ( $\mathrm{HOCl})$ sebagai senyawa turunan $\mathrm{ClO}_{2}$ (terbentuk in situ) yang bereaksi dengan HexA untuk membentuk AOX (Ventorim et al., 2008; Nie et al., 2014). Xylan dari proses pemasakan alkali dapat menghasilkan AOX sebesar 5,0-7,0 $\mu \mathrm{mol} / \mathrm{g}$ tergantung kondisi proses, dan sekitar $3 \mu \mathrm{mol} / \mathrm{g}$ dapat berasal dari senyawa lain seperti lignin pada LCC. Hal ini berarti bahwa nilai AOX yang berasal dari HexA sebesar 9.016.3 mol \% HexA (Magara, Ikeda and Hosoya, 2009).

Tabel 8 menyajikan beberapa penelitian yang mempelajari metode untuk menurunkan kandungan AOX dan pencemar lainnya pada air limbah, yang dilakukan pada kandungan HexA maupun pada proses pemasakan (pulping) dan proses pemutihan pulp. Hubungan antara kandungan HexA terhadap AOX menunjukkan adanya dampak negatif dari terbentuknya kandungan HexA pada pulp terhadap kualitas air limbah.

\section{Proses Dekomposisi Kandungan HexA}

Proses dekomposisi kandungan HexA dapat dilakukan dengan proses kimia ataupun biologi. Dekomposisi kandungan HexA menggunakan proses kimia dapat dilakukan dengan proses/ tahap pemutihan maupun proses pra pengolahan pemutihan seperti proses asam, pemutihan klorin dioksida, pemutihan asam peroksimonosulfat, ataupun pemutihan ozon kuat (Tabel 6). Ikatan HexA yang memiliki struktur ikatan ganda dapat

Tabel 7. Kontribusi HexA pada Bilangan Kappa, Konsumsi $\mathrm{ClO}_{2}$, dan $\mathrm{AOX}$

\begin{tabular}{lccccc}
\hline Fraksi & $\begin{array}{c}\text { Bilangan } \\
\text { Kappa }\end{array}$ & $\begin{array}{c}\text { \% Konsumsi } \\
\mathrm{ClO}_{2}\end{array}$ & $\begin{array}{c}\text { \% Konsumsi } \\
\text { Total } \mathrm{ClO}_{2}\end{array}$ & $\mathrm{AOX}(\mathrm{g} / \mathrm{t})$ & $\begin{array}{c}\text { \% dari Total } \\
\text { AOX }\end{array}$ \\
\hline Proses pencucian & 1,30 & 0,185 & 13,05 & 140,0 & 31,5 \\
Ekstraktif & 1,30 & - & - & 62,0 & 14,0 \\
HexA & 5,19 & 0,600 & 8,64 & 197,0 & 44,3 \\
Grup Karbonil & 0,13 & 0,041 & 3,15 & 8,1 & 1,8 \\
LCC+residu lignin & $1,28+1,80$ & 0,591 & 3,41 & 37,4 & 8,4 \\
\hline
\end{tabular}

Sumber: Costa and Colodette (2007) 
Tabel 8. Pengaruh Beragam Perlakuan terhadap Kualitas Air Limbah

\begin{tabular}{lcc}
\hline Proses & Dampak & Literatur \\
\hline Penurunan kandungan HexA sebelum pemutihan & Menurunkan OX dan AOX & Costa and \\
ECF pada pulp O-bleached Eucalyptus kraft & & Colodette, 2007 \\
Kandungan AOX pada proses pemutihan & Kandungan HexA dari xylan dapat menimbulkan & Magara, Ikeda \\
klorin dioksida pada beech xylan & kandungan AOX pada air limbah & and Hosoya, \\
(4-O-methylglucuronoxylan) dan cellouronate & AOX $=9.0-16.3$ mol \% HexA, atau 5,0-7,0 $\mu \mathrm{mol} / \mathrm{g}$ & 2009
\end{tabular}

Penggunaan tahapan klorin dioksida dengan suhu yang lebih tinggi

$\mathrm{D}_{\mathrm{HT}}$ pada $120 \mathrm{~min} / 95^{\circ} \mathrm{C} / \mathrm{pH} 3$

Dibandingkan tahapan klorin dioksida (D) biasa $\left(30 \mathrm{~min} / 60^{\circ} \mathrm{C}\right.$ ) pada asupan $\mathrm{ClO}_{2}$ yang tetap dan faktor Kappa 0,20

Aplikasi pra emutihan xilanase dan lakase pada pulp Eucalyptus kraft dan pulp kraft bagas

Proses pemutihan menggunakan xilanase (OXAZDP) pada pulp Eucalyptus kraft

Pencucian efisien pada proses pemutihan pada pulp Eucalyptus dan pine kraft yang mengandung HexA

Degradasi lignin akibat proses pemutihan $\mathrm{ClO}_{2}$ pada pulp bagas

Penambahan natrium sulfida $\left(\mathrm{Na}_{2} \mathrm{~S}\right)$ pada stage $\mathrm{E}$ pada pemutihan ECF pulp bagas
Menghasilkan kandungan AOX yang 40-50\% lebih kecil, yang kemungkinan disebabkan karena reaksi klorin dioksida dengan lignin dan HexA yang lebih cepat.

Dapat menurunkan konsumsi bahan kimia klorin lebih dari $15 \%$ sehingga dapat menurunkan kandungan AOX hingga 20-25\%.

Kandungan AOX yang 50\% lebih rendah namun COD, TOC, warna, dan turbiditas menunjukkan angka yang lebih tinggi

Menurunkan COD

Pembentukan AOX akan cepat pada awal proses pemutihan dan akan melambat seiring dengan degradasi lignin
Ventorim,

Colodette and

Eiras, 2009

Thakur, Jain and Mathur, 2012

Fillat et al., 2012

Andrade, Colodette and Oliveira, 2013

Nie et al., 2014

Dapat menurunkan pembentukan AOX hingga $40-50 \%($ dosis $1,5-2 \%, \mathrm{pH} 12,3)$

Keterangan: $\mathrm{COD}=$ chemical oxygen demand

bereaksi dengan beberapa reagen elektrofilik, sehingga HexA berubah menjadi FFA dan FA, namun proses tersebut membutuhkan jumlah energi yang besar dan juga mengakibatkan turunnya sifat pulp, seperti rendemen pulp, kekuatan pulp, sifat hidrofilik dan drainabilitas (Cadena, Vidal and Torres, 2010). Proses dekomposisi HexA pada kandungan hemiselulosa yang lebih rendah juga dapat menghasilkan pulp dengan tingkat kestabilan terhadap kerusakan oksidatif yang lebih tinggi (Zhou et al., 2011).

Proses dekomposisi HexA lain selain menggunakan proses pemutihan, dapat juga dilakukan diantaranya dengan proses pra pengolahan sodium xylenesulfonat (Vivian and da Silva Jr, 2018) dan penggunaan kayu yang mengandung unmethylated glucuronic acid dan bukan 4-O-methylglucuronic acid (Lindström et al., 2011). Kawae dan Uchida (2010b) juga menemukan proses pengurangan efek penguningan tanpa mengurangi kualitas kertas dengan menambahkan pendarihan permukaan yang mengandung asam poly-carboxylic berat molekul rendah maupun tinggi.

Selain menggunakan bahan kimia oksidatif, dekomposisi kandungan HexA juga dapat menggunakan proses aplikasi enzim pada pulp. Penggunaan enzim ini juga dapat menurunkan konsumsi klorin dioksida pada proses pemutihan ECF selanjutnya (Thakur, Jain and Mathur, 2012). Penggunaan lakase dari Trameters villosa (Tvl) dapat menurunkan kandungan HexA hingga 23\% dan menurunkan proses penguningan hingga 8.4\% (Cadena, Vidal and Torres, 2010). Selain itu, penggunaan mediator pada reaksi lakase terhadap kandungan HexA dapat meningkatkan proses penyisihan kandungan HexA pada pulp. Cadena et al., (2011) juga menemukan bahwa lakase dari Tvl memiliki efisiensi penyisihan HexA yang lebih tinggi dengan menggunakan mediator lauryl 
gallate dibandingkan mediator asam $p$-coumaric. Nguyen et al., (2008) menemukan bahwa enzim aksesori dari enzim komersial (lipase komersial) dapat memutihkan pulp kraft dan meningkatkan bleachability lebih tinggi dibandingkan dengan xilanase. Lipase menunjukkan aktivitas spesifik terhadap penurunan HexA dan melepaskan lignin yang menempel pada grup asam tersebut. Penggunaan mediator lakase pada proses pemutihan pulp kraft Eucalyptus globulus yang telah melalui tahap pemutihan oksigen, dapat menurunkan kandungan HexA pada pulp, terutama bila dipadukan dengan aplikasi xilanase sebelumnya (Valls, Vidal and Roncero, 2010). Sementara itu Septiningrum et al., (2015,
2016), menunjukkan potensi enzim yang dapat menurunkan HexA dari Paenibacillus pada pulp kraft Eucalyptus. Beberapa alternatif dekomposisi HexA menggunakan enzim dapat dilihat pada Tabel 9.

Penerapan tahap xilanase dan lakase pada proses pemutihan ECF terbukti lebih baik dalam hal pengurangan konsumsi klorin dioksida dan pengurangan level AOX pada air limbah, serta dapat memperbaiki sifat fisik kertas, dibandingkan penerapan setiap enzimnya secara terpisah (Sharma et al., 2014). Selain enzim tersebut di atas, Kuwabara et al., (2012) juga melaporkan keberhasilan menurunkan kandungan HexA pada LOKP menggunakan enzim hexenuronidase.

Tabel 9. Alternatif Dekomposisi Hexenuronic Acid menggunakan Enzim

\begin{tabular}{l} 
Proses dan Jenis Enzim \\
\hline Aplikasi lipase komersial pada \\
hardwood dan softwood kraft pulp \\
Aplikasi xilanase pada Eucalyptus \\
kraft pulp \\
Aplikasi lakase dan HBT \\
(1-hydroxybenzotriazole), dan \\
aplikasi perlakuan awal xilanase
\end{tabular}

Aplikasi prebleaching xilanase dan lakase pada Eucalyptus kraft pulp dan bagasse kraft pulp

Aplikasi xilanase dan lakase pada proses pemutihan

Aplikasi xilanase dari Bacillus subtilis (aktivitas $400 \mathrm{IU} / \mathrm{mL}$ ) pada bagasse pulp

Aplikasi enzim intracellular dari Paenibacillus pada eucalyptus kraft pulp

Aplikasi enzim extracellular dari Paenibacillus strain 07 pada pulp Eucalyptus kraft

Aplikasi xilanase sebelum pemutihan $\mathrm{H}_{2} \mathrm{O}_{2}$ pada wheat straw chemical pulp dan poplar chemithermo-mechanical pulp

\section{Dapat memutihkan lebih baik dari xilanase komersial. \\ Menunjukkan aktivitas spesifik pada penurunan HexA serta lignin yang terikat padanya. \\ Peningkatan derajat cerah akibat berkurangnya kandungan HexA pada tiga tahap pemutihan hidrogen peroksida pada pulp yang telah diaplikasi enzim \\ Penambahan HBT pada aplikasi lakase memberikan tambahan pada efisiensi reduksi kandungan HexA dan lignin pada pulp. Aplikasi xilanase sebagai perlakuan awal dapat semakin menurunkan kandungan HexA pada tahap Lakase (L)}

Dapat menurunkan konsumsi bahan kimia klorin lebih dari 15\% sehingga dapat menurunkan kandungan AOX hingga $20-25 \%$.

Mengurangi penggunaan $\mathrm{ClO}_{2}$ dan mengurangi $\mathrm{AOX}$ yang terbentuk di air limbah

Penambahan xilanase pada proses pemutihan $\mathrm{ClO}_{2}$ pulp bagas dapat menurunkan kandungan HexA, sehingga lignin dapat lebih bereaksi dengan $\mathrm{ClO}_{2}$ menurunkan konsumsi $\mathrm{ClO}_{2}$ dan kandungan $\mathrm{AOX}$

Dapat menghidrolisis ikatan xylosidic pada $\Delta \mathrm{X} 3$ (model substrat HexA)

Mengindikasikan adanya kandungan enzim yang dapat melepaskan HexA

Aplikasi xilanase pada wheat straw dapat meningkatkan derajat cerah juga mengurangi efek penguningan akibat panas dan cahaya. Efek ini terlihat lebih rendah pada pulp poplar chemi-thermo-mechanical. Hal ini diakibatkan oleh perbedaan kandungan hemiselulosa, HexA, lignin, serta struktur lignin dan aktif grup yang berhubungan dengan kromofor.
Literatur

Nguyen et al., 2008

Shatalov and Pereira, 2009

Valls, Vidal and Roncero, 2010

Thakur, Jain and Mathur, 2012

Sharma et al., 2014

Nie et al., 2015

Septiningrum et al., 2015

Septiningrum et al., 2016

Zhang et al., 2016 


\section{Kesimpulan}

Kandungan HexA dihasilkan dari proses pemasakan kayu alkali kraft yang berasal dari grup 4-O-methyl- $\alpha$-D-glucopyranosyluronic acid (4-O-methylglucuronic acid) pada glucuronoxylan. Proses terbentuknya HexA ini dipengaruhi oleh $H$ factor, spesies kayu, kandungan 4-O-methylglucuronoxylan, perbedaan struktur kayu, efektif alkali dan metode pemasakan. Proses penguningan pulp akibat HexA terjadi setidaknya dengan dua reaksi, pertama terjadi tahap awal yang dipengaruhi oleh suhu (panas), dan satu lagi pada tahap akhir yang dipengaruhi oleh kelembapan atau adanya kadar air.

Selain penyebab proses penguningan pada kertas, kandungan HexA juga dapat meningkatkan konsumsi bahan kimia pada proses produksi pulp dan kertas, terutama pada proses pemutihan dan proses pengujian parameter bilangan Kappa, serta dapat memberikan kontribusi pada kandungan senyawa AOX pada air limbah. Untuk dapat menurunkan kandungan HexA dapat dilakukan dengan diantaranya mengaplikasikan bahan kimia oksidatif, seperti aplikasi proses asam, klorin dioksida, ozon, asam peroksimonosulfat pada proses pemutihan ataupun dengan menggunakan proses enzimatis, seperti penggunaan lakase, xilanase ataupun lipase.

\section{Daftar Pustaka}

Andrade, M. F., Colodette, J. L. and Oliveira, F. N. (2013) 'Evaluation of bleachability on pine and eucalyptus kraft pulps', Cerne Journal, 19(3), pp. 433-439. doi: http://dx.doi.org/10.1590/S010477602013000300010.

Antes, R. and Joutsimo, O. P. (2015) 'Effect of modified cooking on bleachability of Eucalyptus globulus and Eucalyptus nitens', BioResources, 10(1), pp. 597-612.

Bacarin, G. B. et al. (2017) 'The distribution of lignin and xylan in the inner and surface layers of the fiber from eucalyptus kraft pulp and its effects on oxygen delignification', Materials Research, 20(4), pp. 945-950. doi: 10.1590/1980-5373-MR-2016-0687.

Brogdon, B. N. (2009) 'A fundamental review and critical analysis of hexenuronic acids and their impact in elemental chlorine-free bleaching', in TAPPI Engineering, Pulping \& Environmental Conference. Memphis, Tennessee: TAPPI Press, pp. 121-169.
Cadena, E. M. et al. (2011) 'On hexenuronic acid (HexA) removal and mediator coupling to pulp fiber in the laccase/mediator treatment', Bioresource Technology. Elsevier Ltd, 102(4), pp. 3911-3917. doi: 10.1016/j.biortech.2010.11.127.

Cadena, E. M., Vidal, T. and Torres, A. L. (2010) 'Influence of the hexenuronic acid content on refining and ageing in eucalyptus TCF pulp', Bioresource Technology. Elsevier Ltd, 101(10), pp. 3554-3560. doi: 10.1016/j. biortech.2009.11.105.

Chai, X.-S. et al. (2001) 'The fate of hexenuronic acid groups during kraft pulping of hardwoods', in 11th International Symposium on Wood and Pulping Chemistry (ISWPC). Nice, France: Institute of Paper Science and Technology Atlanta.

Costa, M. M. and Colodette, J. L. (2007) 'The impact of Kappa number composition on eucalyptus kraft pulp bleachability', Brazilian Journal of Chemical Engineering, 24(1), pp. 61-71. doi: 10.1590/S010466322007000100006.

Fatehi, P., Malinen, R. and Ni, Y. (2009) 'Bleachability of pulps produced from different kraft pulping Methods: a laboratory study', Pulp and Paper Canada, 110(8), pp. 33-38. Available at: https:// www.pulpandpapercanada.com/paptac/ PDFs/OctNov09/bleaching-comparison. pdf.

Fillat, U. et al. (2012) 'Integrating a xylanase treatment into an industrial-type sequence for eucalyptus kraft pulp bleaching', Industrial and Engineering Chemistry Research, 51(7), pp. 2830-2837. doi: $10.1021 /$ ie202863d.

Gellerstedt, G. (2007) 'the Chemistry of Bleaching and Post-Color Formation in Kraft Pulps', in 3rd International Colloqium on Eucalyptus Pulp (ICEP). Belo Horizonte, Brazil. doi: 10.1007/s13398-014-0173-7.2.

Haroen, W. K. (2016) Teknologi serat bahan baku pulp kertas. Bandung: CV. Agung Ilmu.

Institute for Industrial Productivity (2018) Industrial efficiency technology database: pulp and paper. Available at: http://ietd. iipnetwork.org/content/pulp-and-paper (Accessed: 16 November 2018).

Kawae, A. and Uchida, Y. (2010a) 'Relationship between hexenuronic acid and brightness reversion of ECF-bleached hardwood kraft pulp part II, mechanism of brightness reversion and depressing of the yellowing by size-pressed treatment', Japan Tappi Journal, 64(10), pp. 70-80. 
Kawae, A. and Uchida, Y. (2010b) 'Relationship between hexenuronic acid and brightness reversion of ECF-bleached hardwood kraft pulp part 1', Japan Tappi Journal, 64(2), pp. 170-179. doi: https://doi.org/10.2524/ jtappij.64.170.

Kuwabara, E. et al. (2011) 'Impact on the filtrate from bleached pulp treated with peroxymonosulfuric acid for effective removal of hexenurpnic acid', Japan Tappi Journal, 65(10), pp. 1071-1075. doi: 10.2524/jtappij.65.1071.

Kuwabara, E. et al. (2012) 'Relationship between hexenuronic acid content of pulp and brightness stability in accelerated aging', Japan Tappi Journal, 66(7), pp. 743-757. doi: $10.2524 /$ jtappij.66.743.

Lehtimaa, T. et al. (2010) 'The effect of process variables in chlorine dioxide prebleaching of birch kraft pulp. Part 1. Inorganic chlorine compounds, Kappa number, lignin, and hexenuronic acid content', Journal of Wood Chemistry and Technology, 30(1), pp. 1-18. doi: 10.1080/02773810903276676.

Li, J. et al. (2007) 'An improved methodology for the quantification of uronic acid units in xylans and other polysaccharides', Carbohydrate Research, 342(11), pp. 14421449. doi: 10.1016/j.carres.2007.03.031.

Li, J. and Gellerstedt, G. (1997) 'The contribution to Kappa number from hexeneuronic acid groups in pulp xylan', Carbohydrate Research, 302(3-4), pp. 213-218. doi: 10.1016/S0008-6215(97)00125-0.

Liitiä, T. and Tamminen, T. (2007) 'How to evaluate the kraft pulp stability?', in 3rd International Conference on Eucalyptus Pulp (ICEP). Belo Horizonte, Brazil. Available at: http:/www.eucalyptus.com.br/ icep03/390Liitia.text.pdf.

Lindström, M. E. et al. (2011) 'A genetic strategy for avoiding formation of hexenuronic acid in kraft pulping?', in 5th International Colloqium on Eucalyptus Pulp. Bahia, Brazil: Porto Seguro, pp. 5-8. Available at: http://www.eucalyptus.com.br/artigos/ outros/44_HexAcds_Genetic_Strategy.pdf.

Magara, K., Ikkeda, T. and Hosoya, S. (2009) 'Preparation of hexenuronic acid to estimate the discharge of AOX during $\mathrm{ClO} 2$ bleaching', Japan Tappi Journal, 63(4), pp. 417-425.

Magaton, A. S. et al. (2011) 'Behavior of eucalyptus wood xylans across kraft cooking', Journal of Wood Chemistry and Technology, 31(1), pp. 58-72. doi: 10.1080/02773813.2010.484123.
Nguyen, D. et al. (2008) 'Bleaching of kraft pulp by a commercial lipase: Accessory enzymes degrade hexenuronic acids', Enzyme and Microbial Technology, 43(2), pp. 130-136. doi: 10.1016/j.enzmictec.2007.11.012.

Nie, S. et al. (2014) 'Kinetics of AOX Formation in Chlorine Dioxide Bleaching of Bagasse Pulp', BioResources, 9(3), pp. 5604-5614. doi: 10.15376/biores.9.3.5604-5614.

Nie, S. et al. (2015) 'Removal of hexenuronic acid by xylanase to reduce adsorbable organic halides formation in chlorine dioxide bleaching of bagasse pulp', Bioresource Technology. Elsevier Ltd, 196, pp. 413-417. doi: 10.1016/j.biortech.2015.07.115.

Nie, S. et al. (2016) 'Absorbable organic halide (AOX) reduction in elemental chlorine-free (ECF) bleaching of bagasse pulp from the addition of sodium sulphide', BioResources, 11(1), pp. 713-723. doi: 10.15376/ biores.11.1.713-723.

Pedroso, A. I. and Carvalho, M. G. V. S. (2003) 'Alkaline Pulping of Portuguese Eucalyptus globulus: Effect on Hexenuronic Acid Content', Journal of pulp and paper science, 29(5), pp. 150-154.

Rizaluddin, A. T. et al. (2015) 'Application of peroxymonosulfuric acid as a modification of the totally chlorine-free bleaching of acacia wood prehydrolysis-kraft pulp', Journal of Wood Science. Springer Japan, 61(3), pp. 292-298. doi: 10.1007/s10086-015-1465-z.

Rizaluddin,A.T.etal.(2016)'Peroxymonosulfuric acid treatment as an alternative to ozone for totally chlorine- free and elementary chlorine-free Bleaching of hardwoods prehydrolysis-kraft pulp', Japan Tappi Journal, 70(7), pp. 60-69. doi: 10.2524/ jtappij. 1601.

Septiningrum, K. et al. (2015) 'The GH67 $\alpha$-glucuronidase of Paenibacillus curdlanolyticus B-6 removes hexenuronic acid groups and facilitates biodegradation of themodelxylooligosaccharidehexenuronosyl xylotriose', Enzyme and Microbial Technology. Elsevier Inc., 71, pp. 28-35. doi: 10.1016/j.enzmictec.2015.01.006.

Septiningrum, K. et al. (2016) 'Characterization of hexenuronosyl xylan-degrading enzymes produced by paenibacillus sp. 07', BioResources, 11(1), pp. 2756-2767. doi: 10.15376/biores.11.1.2756-2767.

Sharma, A. et al. (2014) 'Xylanase and laccase based enzymatic kraft pulp bleaching reduces adsorbable organic halogen (AOX) in bleach effluents: A pilot scale study', Bioresource Technology. Elsevier Ltd, 169, pp. 96-102. doi: 10.1016/j.biortech.2014.06.066. 
Shatalov, A. A. and Pereira, H. (2009) 'Impact of hexenuronic acids on xylanase-aided biobleaching of chemical pulps', Bioresource Technology. Elsevier Ltd, 100(12), pp. 30693075. doi: 10.1016/j.biortech.2009.01.020.

Silva, V. L. et al. (2011) 'Factors affecting brightness reversion of hardwood kraft pulps', BioResources, 6(4), pp. 4801-4814.

Takahashi, S., Nakagawa-izumi, A. and Ohi, H. (2011) 'Differential behavior between acacia and Japanese larch woods in the formation and decomposition of hexenuronic acid during alkaline cooking', Journal of Wood Science, 57(1), pp. 27-33. doi: 10.1007/ s10086-010-1143-0.

Tarvo, V. et al. (2010) 'A model for chlorine dioxide delignification of chemical pulp', Journal of Wood Chemistry and Technology, 30(3), pp. 230-268. doi: $10.1080 / 02773810903461476$.

Tarvo, V. (2010) Modeling chlorine dioxide bleaching of chemical pulp. Aalto University.

Tavast, D. et al. (2011) 'Selectiveness and efficiency of combined peracetic acid and chlorine dioxide bleaching stage for kraft pulp in removing hexeuronic acid', Cellulose Chemistry and Technology, 45(1-2), pp. 89-95.

Teleman, A. et al. (1996) 'Identification of the acidic degradation products of hexenuronic acid by NMR spectroscopy', carbohydrate Research, 280, pp. 197-208.

Thakur, V. V., Jain, R. K. and Mathur, R. M. (2012) 'Studies on xylanase and laccase enzymatic prebleaching to reduce chlorinebased chemicals during $\mathrm{CEH}$ and ECF bleaching', BioResources, 7(2), pp. 22202235. doi: 10.15376/biores.7.2.2220-2235.

Valls, C., Vidal, T. and Roncero, M. B. (2010) 'The role of xylanases and laccases on hexenuronic acid and lignin removal', Process Biochemistry, 45(3), pp. 425-430. doi: 10.1016/j.procbio.2009.10.015.

Ventorim, G. et al. (2008) 'Reaction rates of lignin and hexenuronic acids with chlorine dioxide, ozone, and a sulfuric acid', Wood and Fiber Science, 40(2), pp. 190-201.

Ventorim, G., Colodette, J. L. and Eiras, K. M. M. (2009) 'The fate of chlorine species during high temperature chlorine dioxide bleaching', Nordic Pulp and Paper Research Journal, 70(8), pp. 39-50. Available at: papers $2: / /$ publication/uuid/4E7E683DDA1F-4025-9CBD-D843B22AFD7A.
Ventorim, G., Favaro, J. S. C. and Frigieri, T. C. (2016) 'Effect of kraft pulping temperature and alkalinity on eucalyptus ecf bleaching', Cellulose Chemistry and Technology, 50(910), pp. 1025-1033. doi: http://hdl.handle. net/11449/162553.

Vivian, M. A. and da Silva Jr, F. G. (2018) 'S cientia F orestalis Effect of eucalyptus wood chips pretreatment with sodium xylenesulphonate ( SXS ) in the kraft cellulosic pulp quality Efeito do pré-tratamento dos cavacos da madeira de eucalipto com xilenosulfonato de sódio ( SXS ) na qualidade da', Scientia Forestalis, 46(118), pp. 261-269. doi: dx.doi. org/10.18671/scifor.v46n118.12 261.

Vourinen, T. et al. (2007) 'Reactivity of hexenuronic acid in bleaching of eucalyptus kraft pulps', in 3rd International Colloquium on Eucalyptus Kraft Pulps. Belo Horizonte, Brazil. Available at: http://www.eucalyptus. com.br/icep03/210Vuorinen.text.pdf.

WWF (2018) Responsible forestry: pulp and paper. Available at: https://www. worldwildlife.org/industries/pulp-and-paper (Accessed: 16 November 2018).

Yoon, K. et al. (2012) 'Relationship between hexenuronic acid contents of pulp and brightness stability-peroxymonosulfuric acid treatment for effective removal of hexenuronic acid', in Pulp Paper Resources Conference. Tokyo: Japan TAPPI, pp. 48-53.

Yoshida, K. and Koshitsuka, T. (2008) 'On-site production of peroxymonosulfuric acid for hexenuronic acid removal from kraft pulp', in International Pulp Bleaching Conference. Quebec: PAPTAC, pp. 165-168.

Zhang, D. et al. (2016) 'Xylanase treatment suppresses light-and heat-induced yellowing of pulp', Scientific Reports. Nature Publishing Group, 6(November), pp. 1-9. doi: 10.1038/srep38374.

Zhou, Z. et al. (2011) 'Brightness reversion of eucalyptus kraft pulp: Effect of carbonyl groups generated by hypochlorous acid oxidation', Holzforschung, 65(3), pp. 289294. doi: 10.1515/hf.2011.047. 
Lurnal Selulosa, Vol. 8, No. 2, Desember 2018:61- 76

- Halaman ini sengaja dikosongkan - 